\section{Charles Vest is new president}

\section{Boston}

AfTER several false starts and a renewed extended search, the Massachusetts Institute of Technology (MIT) has officially chosen its new president. Charles M. Vest, a 48-year old mechanical engineer who is now provost of the University of Michigan, has accepted the job and been formally approved by the MIT Corporation, and is due to begin as MIT's fifteenth president in mid-October this year. At his first news conference at MIT, Vest bemoaned the state of US competitiveness, saying that "large segments of the nation have lost the will to excel". He pledged a "fundamental reassessment of engineering education".

Several leading contenders removed themselves from consideration, and one, biologist Phillip Sharp, declined the job a week after his selection was formally announced. Vest said he is "proud to be a colleague" of someone like Sharp who puts his research above his desire to be an administrator, and brushed aside comments about the long, tumultuous search. Seth Shulman

\section{JAPANESE SCIENCE}

\section{Land of rising publication}

\section{Washington}

IN the past decade, Japanese researchers have increased their representation in the pages of leading international science journals by over 50 per cent, according to a new survey in Science Watch, a newsletter published by the Institute for Scientific Information.

Organic chemistry leads the list of improved Japanese research fields, as measured by journal publication. The five leading chemistry journals recorded an increase in Japanese papers from 8.8 per cent in the first half of the decade to $\mathbf{1 1 . 3}$ per cent in the second half. Applied physics research, especially in the fields of solid state and condensed-matter physics, has been another strong area for Japanese scientists in the 1980s. Representation in top physics journals jumped from 5.1 per cent to 8.5 per cent over the decade.

Biology is the third area in which Japan has shown marked improvement in journal publication. Representation in the five leading biology journals increased from 3.3 per cent to 5.9 per cent in the past decade. But in the two leading multidisciplinary journals, Science and Nature, Japanese representation has grown only slightly. Nature continues to publish more than twice as many Japanese papers as Science: the ratio is now 1.8 per cent to 0.8 per cent, as compared to 1.6 per cent to 0.7 per cent a decade ago.

G. Christopher Anderson

\title{
Problems of streamlining
}

\section{Munich}

WITH the steamroller of German unification fast approaching, the East German Academy of Sciences last week began the awesome task of stripping away 14,000 of 24,000 jobs in order to create a streamlined core that can be integrated into West German science. Pressure from both the recent currency union and shrinking funds for science forced the East German government to give the academy only until the end of the year to complete its changes. Research institute directors did not learn of this decision until a meeting at the Adlershof research campus in East Berlin on 25 June.

Even the planned reduction will probably not be enough to satisfy the West Germans who will hold the purse-strings for science in a unified Germany. The number of employees who survive the academy cuts is likely to be under 10,000 - but even the renowned Max Planck Gesellschaft of West Germany has just 13,000 employees. That means that an academy with 10,000 employees may still seem excessive when the two German states are unified politically, a step now likely to take place in December. The academy will lose nearly half its budget as the industrial Kombinate, which provided support for contract research, disappear in the face of West German competition.

The East German Research Ministry, which is responsible for the academy in the current East German government, has promised to do its best, but is unlikely to be able to take up all the slack as funds disappear. East German Research Minister Frank Terpe said just two weeks ago that he would try to provide a twoyear 'moratorium' on the closing of academy institutes to allow time for restructuring and for the influential West German science advisory council (Wissenschaftsrat) to survey academy research projects and recommend changes.

But this timetable is proving too slow for the West German Research Ministry (BMFT) which will take responsibility for the academy in a unified Germany. A BMFT spokesman says that the ministry cannot wait the 18 months requested by the Wissenschaftsrat to see which institutes and groups should survive, but would prefer a "rough assessment" to be completed by December. Though this is "not a perfect solution", he said, "we will try to push in this direction. No matter how much is required for the evaluation", he added, "money will be no obstacle." Wissenschaftsrat will have practical problems carrying out the evaluation so quickly. "It will be hard to get the experts in on short notice," warned Wissenschaftsrat chairman Dieter Simon.

West German Research Minister Heinz
Riesenhuber will meet Terpe, East German Education Minister Hans Joachim Meyer and the heads of West German science organizations this week in order to try to force the pace.

The new East German scientific leaders have additional worries. Benno Parthier, just appointed director of an academy research institute in Halle and presidentelect of the Akademie Leopoldina, said that such a quick change would not leave time for a "differentiated look" at what East German science could do.

Horst Klinkmann, a medical researcher in Rostock who last week became the first democratically elected president of the academy, said that if there is not enough time to adapt, it will leave a "scientific vacuum" in East Germany that could destroy the economy.

BMFT wants different institutes to receive different treatment. Some would be shut down or sold to industry - these would be easy to identify, according to a BMFT spokesman. Others will be maintained, after excess has been pared away, as institutes for applied research under the Fraunhofer Gesellschaft or perhaps even as part of the Large Research Establishments (Grossforschungseinrichtungen). There will be plenty of painful choices, especially within institutes that have to be reduced in size, "I have to consider the existence of the institute first, before the jobs of individual employees," said Parthier, who is giving up his summer holiday to begin the task. "But I have known these people for many years, and it is not their fault that they are in this position.'

East Germans who had hoped for salvation through the Max Planck Gesellschaft (MPG) will be sorely disappointed by the announcement at the MPG annual meeting in Lübeck on 20 June that East German institutes would not be absorbed. Incoming MPG president Hans Zacher said the dialectical approach to science in East Germany had "turned on its head" the successful West German approach (which originated in the nineteenth century under the Reich) allowing freedom of research with generous state and industry support. "Trying to unify the two systems could destroy them both", he warned. "There is a lot of useful research in East Germany. . . Our problem is how to integrate it into a system based on freedom without changing ourselves." Simon, who is also director of a Max Planck Institute, considers such fears unreasonable. "We will not be 'infected' by the East German mentality, as some are supposing", he added. "Instead", he said, "we have to develop a "we' mentality" together with the East Germans.

Steven Dickman 